\title{
The role of covenants in bond issue. The case of Russian companies.
}

\author{
Flavio Bazzana ${ }^{\mathrm{a}, *}$, Anna Zadorozhnaya ${ }^{\mathrm{b}}$, Roberto Gabriele ${ }^{\mathrm{a}}$ \\ ${ }^{a}$ University of Trento, Trento, Italy \\ ${ }^{b}$ Moscow State University of Railway Engineering, Moscow, Russian Federation
}

\begin{abstract}
This study examines the use and determinants of covenants in public debt issued by Russian companies. Based on issue characteristics and firm characteristics, we investigate the likelihood that the inclusion of covenant clauses in financial contracts is positively related to the riskiness of bond issues. Using a hand-collected database of Russian firms that place bonds in both the domestic and Eurobond markets, we provide evidence that Russian bondholders use covenant protection to compensate for different creditor protections when the firm has Eurobonds in its debt portfolio. We also find a general negative relation between covenant protection and the bond's yield.
\end{abstract}

Keywords: covenants, bond, Russian companies

JEL: G31, G32

\section{Introduction}

An extensive body of theoretical and empirical research on capital structure has expanded beyond the choice of debt versus equity and increasingly examines the architecture of corporate liabilities, including characteristic features of financial contracts.

5 Covenants are particular clauses in an indenture or any other formal debt agreement that restrict corporate policy, providing creditors with the opportunity to enforce certain actions (e.g., to demand early repayment) when these covenants are breached. At the centre of the rationale for the presence of covenants in financial contracts is the conflict of interest between shareholders and debtholders 1 This conflict results in 10 actions undertaken by managers acting on behalf of shareholders that have a negative impact on both the firm's value and the market value of outstanding debts. Studies by Jensen \& Meckling (1976), Myers (1977), and Smith Jr \& Warner (1979) identify four main sources of conflict: claim dilution, asset withdrawal, asset substitution and underinvestment. One way to mitigate these conflicts and reduce the attendant 15 agency costs is to include appropriate covenants in debt contracts to influence a firm's financial and investment policies and to lower the transfer of wealth to shareholders. However, covenants may produce undesirable effects, reducing flexibility in corporate

\footnotetext{
* Corresponding author

Email addresses: flavio.bazzana@unitn.it (Flavio Bazzana), anna_zador@mail.ru (Anna Zadorozhnaya), roberto.gabriele@unitn.it (Roberto Gabriele)

${ }^{1}$ Recently, Demerjian (2017) revised this explanation for covenant use, arguing that financial covenants facilitate contracting under uncertainty.
} 
policy by restricting future financing and investment decisions. Firms with high investment opportunities prefer to have few restrictive covenants because they seek to 20 preserve future financial and investment opportunities (Beatty et al. 2002, Nash et al. 2003; Billett et al., 2007). At the same time, the costly contracting hypothesis (CCH) by Smith Jr \& Warner (1979) further sharpens this insight by arguing that, due to reduced agency risk, firms optimally trade off the cost of the restrictions imposed by covenants with a lower cost of debt.

The empirical literature has demonstrated the increasing rate at which covenants are included in public and private debt contracts (Billett et al., 2007, Nini et al., 2009; Kwan \& Carleton, 2010). However, extant research on the agency theory of covenants (ATC) relies on data from the United States and other developed countries. Moreover, the U.S. and other markets show marked differences. Regarding the U.S.

30 market, broad empirical research provides evidence that most corporate debt contracts include covenant protections in both public and private debt (Smith Jr \& Warner, 1979, Dichev \& Skinner, 2002, Nash et al., 2003, Bradley \& Roberts, 2015, Chava et al. 2004, Chava \& Roberts, 2008; Chava et al., 2010, Demiroglu \& James, 2010). Nevertheless, Smith Jr \& Warner (1979) argue that "we must examine the institutional

35 framework within which covenant enforcement takes place for further insight into why certain kinds of covenants are observed-and others not" (p. 147). Thus, empirical research conducted outside the U.S. market reveals that covenant provisions are not ubiquitous in either public or private debt contracts (Niskanen \& Niskanen, 2004; Mather \& Peirson, 2006, Correia, 2008, Tanigawa \& Katsura, 2013). For instance,

40 investigating the UK Eurobond market, Correia (2008) shows that only 33 percent of the total sample of issues include more than one covenant. Similarly, in an analysis of Finnish small firm loans, Niskanen \& Niskanen (2004) indicate that, on average, only 11.2 percent of loan contracts include at least one covenant. Finally, by studying Japanese corporate publicly issued bonds, Tanigawa \& Katsura (2013) register that

4520.3 percent of issues do not contain any covenant clauses.

The examination of contracts from other environments broadens the evidence supporting ATC and the cost-contracting hypothesis $(\mathrm{CCH})$. For instance, observing a sample of Brazilian indenture agreements, Anderson (1999) argues that a weak institutional environment affects the nature of financial contracting. More importantly, due

50 to the potential conflicts between shareholders and creditors, the agency costs of debt are likely to be high in Brazil. However, covenants that restrict a debtor's dividend, investment, and financing policies are seldom observed in the sample of indentures. Due to poor data availability, there is a substantial lack of empirical evidence on covenant protection and its determinants in less-developed markets.

To the best of our knowledge, this paper is the first to investigate the determinants of covenant clauses by considering a sample of Russian bond issues. A distinguishing feature of the Russian debt market is that certain borrowers place bonds on both the domestic bond market (in rubles under Russian law) and the Euromarket (mostly in USD under English law) simultaneously. Moreover, according to statistics, the total

60 volume of outstanding Eurobond issues is comparable to the domestic bond market in size. To address this, we collect broad and in-depth data from both domestic bond issues and Eurobonds placed by Russian companies. The recent finance literature argues that the differences in legal and institutional environments play an important role in the optimal use of debt contract terms, including covenants (Djankov et al.,

65 2007; Qi \& Wald, 2008; Qi et al., 2011). Using data on bonds from both the domestic market and the Euromarket makes it possible to demonstrate the cross-market differences in creditor protection and to estimate the influence of Eurobonds' terms on the 
covenant set included in Russian debentures of the same companies.

Additionally, we construct a firm-year sample to investigate the relation between covenant protection and different types of firms. The analysis examines not only the determinants of the inclusion of covenants in debt issues but also the ways in which the difference between the Russian corporate bond market and the Euromarket influences issuers' behaviours in offering covenant protection. We specifically focus on the influence of covenant provisions on the cost of debt. Thus, our paper yields new 75 results and important insights for credit rating agencies and for creditors and investors that operate in Russian financial markets.

We organise the remainder of the paper as follows. Section 2 develops testable hypotheses on the relation between covenant protection and the characteristics of issues and firms. This section also describes how covenant clauses in indenture agreements can affect the cost of debt. Section 3 describes the sample and provides descriptive statistics on the issuers and characteristics of debt, including the frequency of covenant usage. Section 4describes the methodological aspect of the empirical model, and Section 5 discusses the results. In Section 6, we present some robustness checks, and Section 7 concludes the paper.

\section{Empirical predictions}

We investigate how covenant protection is related to firm characteristics and to the features of issues and how it influences firm value. With respect to firm and issue characteristics, we focus on the determinants of the choice of covenant protections (Hypothesis 1). Furthermore, we investigate how the differences between the Russian corporate bond market and the Euromarket influence issuers' behaviour in offering covenant protection (Hypothesis 2). With respect to the differences between the two markets, we analyse how covenant protection affects the cost of debt (Hypothesis 3).

Hypothesis 1. The likelihood of including covenants will be positively related to the riskiness of the issue.

An extensive body of empirical literature on covenants focuses on the factors that determine the choice of covenants in debt issues. According to the Agency Theory of Covenants (Bradley \& Roberts, 2015), which provides a rationale for the presence of covenants in debt indentures, as bond riskiness increases, the likelihood of covenant inclusion increases. In the literature, three principal variables are used to proxy for

100 the riskiness of the issue in relation to covenant protection: ( $i$ ) debt maturity, (ii) firm growth, and ( iii) firm size. As Myers (1977) argues, when a firm has risky debt outstanding and when managers act to maximise equity value on the basis of risk-shifting, managers have incentives to under- or overinvest in future growth opportunities. In this case, covenant protection and debt maturity become significant components of mitigating shareholder-bondholder conflicts. More generally, Barnea et al. (1981), and Childs et al. (2005) note that short-term debt can mitigate both underinvestment and overinvestment problems by making debt less sensitive to changes in firm value. A number of empirical studies (Barclay \& Clifford W Smith, 1995; Guedes \& Opler, 1996; Aivazian et al. 2005) support this statement. However, using short-term financing to

110 reduce agency costs may increase the cost of debt through both higher refinancing risk and higher transaction costs of debt rollover. Consistent with the interpretation of the substitution of short-term debt with no covenants and long-term debt with covenants, Bradley \& Roberts (2015) find that long maturity and the presence of covenants are positively related. 
The contracting literature (Myers, 1977) suggests that firms with higher growth and/or investment opportunities are likely to face risk-shifting problems in the future (or transfers of wealth from debtholders to shareholders). Therefore, bondholders, particularly in high-growth firms, have incentives to protect themselves from managerial discretion (which might result in asset substitution, underinvestment, or claim Billett et al. (2007) find a positive relation between covenant protection in public debt contracts and growth opportunity. Similarly, Bradley \& Roberts (2015) and Demiroglu \& James (2010) study private debt agreements and find a positive relation between growth opportunity (measured by the market-to-book ratio) and covenant protection. By contrast, Kahan \& Yermack (1998) and Nash et al. (2003) examine the relation between a firm's growth opportunity and the choice of covenants in public debt issues. Both studies find that high-growth firms are less likely to include restrictive covenants, suggesting that the benefit of preserving future flexibility outweighs the benefit of reducing the cost of debt by including covenants.

By investigating three types of covenants (dividend constraints, limitations on debt, and sinking funds), Malitz (1986) notes that larger firms have longer-standing relationships with the market. Assuming that having more firm-specific information allows bondholders to more accurately assess potential wealth-expropriating decisions, thus lowering the need to offer costly covenants, Malitz (1986) finds that as firm 135 size increases (measured by the natural log of total assets), the firm's likelihood of benefiting from restrictions increases. In spite of the conventional wisdom of a negative relation between the issuer's size and covenant protection, Nash et al. (2003) and, later, Bradley \& Roberts 2015) note that size affects different types of covenants differently.

Hypothesis 2. In order to compensate for different levels of credit protection, covenant protection is higher for a firm that has Eurobonds in its debt portfolio.

The Eurobond market differs from the Russian corporate bond market in four key areas: $(i)$ all issues of Eurobonds contain protective covenants in bond indenture agreements, in contrast to Russian corporate bonds, (ii) higher transparency requirements for bond issuers, (iii) greater coordination among bondholders when in technical default, and $(i v)$ the existence of a bond trustee as a financial institution that acts as go-between for a bond issuer and bondholders. In July 2014, Russian law introduced bondholders' representatives to perform a similar function to the trustee in a Eurobond transaction. In addition, Russian laws require issuers to add to bond indenture agreements the conditions of early redemption at the request of debtholders. However, lenders have the right to call for early redemption in few cases: delayed payment of the coupon and principal of the bonds for ten working days and the loss of collateral or the significant deterioration of the collateral provision quality. Moreover, according to the World Bank's 2015 Doing Business Survey, Russia ranks 100th in the world in terms of minority investor protection.

155 Another aspect regards covenant violations. In fact, covenant violations trigger a renegotiation process in which the right to accelerate debt assigns a high amount of bargaining power to debtholders. This bargaining power can significantly change the terms of the debt; for instance, it can increase the interest rate spread, reduce the maturity, restrict the availability of the credit line, require additional collateral and/or contain more restrictive covenants on cash management and capital expenditure (Nini et al. 2012). In other words, covenants provide an opportunity for debtholders to support the borrower when a covenant breach occurs (Prilmeier, 2017). This bargaining power also depends on the law under which the debt was issued - in our case, between 
Russian law and English law2

All these different aspects between the two markets can be captured by the creditor protection index originally proposed by La Porta et al. (1997) and computed - with minor differences - for 129 countries by Djankov et al. (2007). The index ranges from 0 in the case of weak creditor rights to 4 in the case of strong creditor rights. Regarding the relation between credit protection and the use of covenants, Qi \& Wald (2008) and Qi et al. (2011) provide the most interesting results. In particular, Qi et al. (2011) compute the index for more than 50 countries: the index for Russia was 1.9 and that for the United Kingdom was 4.0, indicating a strong difference between the two countries. If, as in our case, the firm issues different bonds in different markets, we assume that the relationships with the capital market can be different.

Considering the difference between the two countries in terms of laws of issue, we expect that Russian bondholders can require more covenants on a domestic issue if the firm has Eurobonds in its portfolio in order to compensate for the difference in creditor protection.

Hypothesis 3. Bond yield will be negatively associated with the level of covenant protection.

According to the CCH and documented by Smith Jr \& Warner $(1979)$ in their seminal paper, because covenant restrictions are costly to a firm, they must confer some offsetting benefit. These authors argue that this benefit is the reduction of agency costs, which translates into a lower cost of debt. More recently, a series of articles have examined the joint choice and price effect of covenants in large samples of debt issues. Gong et al. (2017), Reisel (2014), Chava et al. (2010), and Wei (2005) examine public debt issues, whereas Goyal (2005) adapts this methodology to study the impact of covenants on the spread of bank-issued subordinate bonds and Bradley \& Roberts (2015) use this methodology to study the impact of covenants on bank loan spreads. All these articles find that including covenants reduces the cost of debt. In particular, Reisel (2014) finds a reduction of approximately 35-75 basis points. Additionally, Goyal (2005) and Bradley \& Roberts (2015) find that whether to include restrictive covenants and to decide corporate debt yield are determined simultaneously because management trades off the flexibility and other costs of covenant inclusion with a reduction in the expected offering yield (or cost of debt), while the equilibrium offering yield depends on the included covenants.

In contrast, covenant protection provided to investors is subject to a number of parameters that define an issuer's risk profile. These, in turn, are likely to depend on the issuer's characteristics, which will influence the investors' perception of the credit risk. Moreover, investors may determine the terms of the debt, including the covenant protection, to suit the firm's risk profile. Thus, by examining corporate bonds publicly issued in Japan from January 4, 2000, to December 20, 2011, Tanigawa \& Katsura (2013) reveal that the relation between covenant usage and cost of debt varies across segments, with a tendency to follow issuers' credit rating. As an illustration, average yield spreads are smaller when protective power is stronger within both AAA-rated and AA-rated bond classes. However, for A-rated, BBB-rated, and BB-rated bonds, the protective power does not conform to the average yield spread. For instance,

\footnotetext{
${ }^{2}$ Russian firms normally issue on the Eurobond market under English law. In our sample, fully described in Section 3 the $100 \%$ of the issues in the Eurobond market were under English law, with 95\% of them in United Kingdom, and 5\% in Luxembourg.
} 
the average yield spread for A-rated uncollateralised bonds with all three covenant clauses is the highest among A-rated uncollateralised bonds. This finding indicates that a covenant clause is chosen endogenously and could be appraised by investors as a signal of higher risk. Accordingly, investors require a higher yield to compensate for the risk inherent in bonds, and the bond also needs a censoring clause attached in order to place the bond successfully.

\section{Data and sample construction}

The final database we use is built using two different samples. The first contains data related to the characteristics of the bond issues, and the second contains data on the firms issuing the bonds.

\subsection{The bond issue sample}

Our main data source is the Cbonds database (Cbonds.ru), which contains issue details on various financial market instruments (bonds, syndicated loans, stocks, mutual funds, etc.) from Russia, the CIS, and emerging markets. Cbonds.ru provides detailed information on bonds, including offering yield, offering amount, coupon type and rate, maturity, callability and putability features, as well as quotes and indices. According to the majority of market participants, the Cbonds database for CIS countries is more accurate than databases of other Russian and international data vendors. Because our objective is to examine the influence of shareholder-bondholder conflicts on corporate financial and investment policy, we focus on corporate public bonds outstanding in the domestic market of Russia and Eurobonds issued by Russian companies. Although Cbonds.ru contains corporate bonds issued as early as 1999, we clauses became slightly more comprehensive. After excluding financial firms, finance subsidiaries and a small number of offerings with missing data, we obtain an initial sample of 814 non-convertible bonds issued by industrial companies and utilities from 2008 to 2013 (Tab. 1).

${ }_{235}$ Panel A of Tab. 1 reports the distribution of domestic corporate bond issues by different categories and the average level of basic bond characteristics over time. From the year 2008 to the end of 2013, 237 non-financial issuers in various industries placed 654 issues (all in rubles) for a total face value of approximately 3,459.3 billion rubles (over 115 billion USD). Data analysis shows a fluctuation in the amount of outstand-

240 ing bonds. Despite the significant drop by almost $32 \%$ in 2010 , the face value of corporate bonds issued in 2013 grew more than twofold in comparison with 2008. The slight decrease in the number of issuers to 62 (in comparison with 65 in 2008) was accompanied by growth in the number of issues by almost $40 \%$ to 117 (in comparison with 84 in 2008). This indicates two main tendencies. First, the size of an individual

245 bond issue tends to climb. Second, during the period of observation, the expansion of the domestic corporate bond market was not attributable primarily to new issuers.

The credit risk of major corporate bonds is measured by international agencies (Moody's, Standard and Poor's, and Fitch) and a number of domestic rating agencies (Expert RA, and RA AKM). We focus on the international ratings. We structure 250 the credit ratings in the following way: $(i)$ investment grade - bonds that have Standard and Poor's and Moody's credit ratings over BBB-(Baa3); (ii) below investment grade - with credit ratings less than $\mathrm{BB}+(\mathrm{Ba} 1)$; (iii) not rated, and (iv) bonds with withdrawn international ratings. The majority $(73.8 \%)$ of Russian outstanding corporate bonds did not have an international rating in 2008. Since the economic crisis 
Table 1: Issue characteristics of domestic corporate bonds (Panel A) and Eurobonds (Panel B) for all years of the sample divided by $(i)$ issue characteristics and $(i i)$ rating.

\begin{tabular}{|c|c|c|c|c|c|c|c|}
\hline \multirow{2}{*}{ Variables } & \multicolumn{6}{|c|}{ Issuance period } & \multirow{2}{*}{ Full sample } \\
\hline & 2008 & 2009 & 2010 & 2011 & 2012 & 2013 & \\
\hline \multicolumn{8}{|c|}{ Panel A: domestic corporate bonds } \\
\hline Firm & 65 & 56 & 64 & 61 & 58 & 62 & 237 \\
\hline Issues & 84 & 93 & 104 & 157 & 99 & 117 & 654 \\
\hline Mean of issues per firm & 1.3 & 1.7 & 1.6 & 2.6 & 1.7 & 1.9 & 2.8 \\
\hline \multicolumn{8}{|l|}{ Issue characteristics } \\
\hline Mean of covenant per issue & 0.8 & 1.8 & 1.8 & 1.1 & 1.5 & 1.2 & 1.35 \\
\hline Yield $(\%)$ & $12.98 \%$ & $14.82 \%$ & $9.65 \%$ & $8.95 \%$ & $10.09 \%$ & $9.79 \%$ & $10.88 \%$ \\
\hline Amount (mln rub) & 300,142 & 706,173 & 482,113 & 617,478 & 493,493 & 859,894 & $3,459,291$ \\
\hline Amount per issue (mln rub) & $3,573.1$ & $7,593.3$ & $4,635.7$ & $3,908.1$ & $5,035.6$ & $7,349.5$ & $5,289.4$ \\
\hline Aver. time to maturity (yrs) & 3.41 & 4.64 & 4.92 & 4.54 & 6.42 & 8.99 & 5.55 \\
\hline Average coupon rate $(\%)$ & $12.47 \%$ & $14.19 \%$ & $9.21 \%$ & $8.79 \%$ & $9.83 \%$ & $9.48 \%$ & $10.48 \%$ \\
\hline \multicolumn{8}{|l|}{ Rating } \\
\hline Not rated & $73.81 \%$ & $35.48 \%$ & $39.42 \%$ & $25.48 \%$ & $30.30 \%$ & $32.48 \%$ & $37.31 \%$ \\
\hline Withdrawn & $9.52 \%$ & $6.45 \%$ & $9.62 \%$ & $0.64 \%$ & $44.44 \%$ & $3.42 \%$ & $4.43 \%$ \\
\hline Below investment grade & $13.10 \%$ & $24.73 \%$ & $37.50 \%$ & $23.57 \%$ & $2.02 \%$ & $29.91 \%$ & $28.90 \%$ \\
\hline Investment grade & $3.57 \%$ & $33.33 \%$ & $13.46 \%$ & $50.32 \%$ & $23.23 \%$ & $34.19 \%$ & $29.36 \%$ \\
\hline \multicolumn{8}{|l|}{ Panel B: Eurobonds } \\
\hline Firm & 17 & 11 & 18 & 10 & 16 & 26 & 61 \\
\hline Issue & 25 & 27 & 24 & 18 & 25 & 41 & 160 \\
\hline Mean of issues per firm & 1.5 & 2.5 & 1.3 & 1.8 & 1.6 & 1.6 & 2.6 \\
\hline \multicolumn{8}{|l|}{ Issue characteristics } \\
\hline Mean of covenant per issue & 7.6 & 7.9 & 7.8 & 7.8 & 9.5 & 9.3 & 8.5 \\
\hline Yield (\%) & $10.51 \%$ & $8.73 \%$ & $6.83 \%$ & $6.32 \%$ & $5.11 \%$ & $4.84 \%$ & $6.81 \%$ \\
\hline Amount (mln usd) & 14,075 & 12,781 & 12,952 & 11,44 & 18,71 & 29,792 & 99,751 \\
\hline Amount per issue (mln usd) & 563.01 & 473.37 & 539.70 & 635.56 & 748.41 & 726.65 & 623.45 \\
\hline Aver. time to maturity (yrs) & 4.54 & 2.99 & 6.09 & 6.31 & 5.33 & 6.40 & 5.31 \\
\hline Average coupon rate $(\%)$ & $10.18 \%$ & $9.13 \%$ & $7.01 \%$ & $6.51 \%$ & $5.58 \%$ & $5.06 \%$ & $7.04 \%$ \\
\hline \multicolumn{8}{|l|}{ Rating } \\
\hline Not rated & $24 \%$ & $3.70 \%$ & $16.67 \%$ & $0 \%$ & $8 \%$ & $4.88 \%$ & $9.38 \%$ \\
\hline Withdrawn & $28 \%$ & $7.41 \%$ & $8.33 \%$ & $0 \%$ & $48 \%$ & $0 \%$ & $6.88 \%$ \\
\hline Below investment grade & $28 \%$ & $33.33 \%$ & $50.00 \%$ & $66.67 \%$ & $40 \%$ & $43.90 \%$ & $43.75 \%$ \\
\hline Investment grade & $20 \%$ & $55.56 \%$ & $25.00 \%$ & $33.33 \%$ & $4 \%$ & $51.22 \%$ & $40.01 \%$ \\
\hline
\end{tabular}

255 of 2008-2009, the situation has changed dramatically. The worsening of the macroeconomic situation enabled growth in the number of defaults of unrated bonds and difficulties with restructuring. Due to uncertainty and high volatility in financial markets, investors became more risk-averse. The main direction of the change in the structure of the Russian corporate bond market is a substantial increase in the number of investment-grade bonds from 3.5\% in 2008 to $34 \%$ in 2013.

There has been an upsurge in interest in the Eurobond market from the Russian corporate sector since the year 2006-2007. Some insight into the reason for this behavior of Russian issuers can be found in the lack of market depth and duration in the domestic bond market. In contrast, the distinguishing features of the Euromarket are mandatory international issuer ratings; as a rule, stock exchange listings; compliance with the requirements of local securities regulators (e.g., UKLA); the presence of covenants in indenture agreements, including cross-default; and strict disclosure requirements. Additionally, a Eurobond issue is considered to be qualified as a liquid asset if its amount is higher 500 million USD. Obviously, it can be asserted that issuing financial instruments such as Eurobonds is available to large companies with 
relatively high levels of financial stability.

Panel B of Tab. 1 presents the distribution of 160 Eurobonds issued by Russian companies and the average level of basic bond characteristics over time. According to Cbonds.ru, during the period of observation, the total volume of outstanding Eurobond issues accounts for 99.8 billion USD, which seems comparable to the domestic bond market in terms of size. External corporate bond debt increased considerably in 2012. As opposed to the domestic corporate bond market, the volume of outstanding bank Eurobonds is less than the volume of Eurobonds floated by nonfinancial companies. The number of outstanding Russian corporate Eurobond issues exceeded 40 in 2013, compared with 25 issues in 2008. Borrowings were denominated mostly in USD (134 issues out of 160, worth a total of 83.2 billion USD). However, Russian companies borrowed by means of Eurobonds in euros, pounds, Swiss francs, new Israeli shekels, and Russian rubles.

Russian corporate borrowers placed their Eurobonds on the same five stock exchanges. The Irish Stock Exchange retained its leading position in terms of the number of Eurobond placements. Russian corporate borrowers' interest in Eurobond placements on the Irish Stock Exchange was justified. Despite the issuers' comparable underwriting expenses, the total cost of placement on the Irish Stock Exchange, together with other flotation costs (listing application fees, tranche listing fees, etc.), may be lower than the cost of flotation on the London Stock Exchange, which also remains popular among Russian issuers. Moreover, companies established in Ireland for the purpose of floating securities on the local stock exchange benefit from the country's lower taxes.

Global investors' persistent interest in Russian securities in the period of observation contributed to the relatively low cost of borrowing for Russian companies, while the average term of borrowed funds increased further from 4.5 years in 2008 to 6.4 years in 2013. In 2009 and in the second half of 2011, the negative performance of international financial markets and the over-indebtedness of some European countries encouraged investors to shift their preferences towards less risky instruments.

The main variable of interest in this work is the inclusion of covenant clauses in bond indentures. Therefore, we manually collected and analysed 654 prospectuses of Russian corporate bonds and 160 indentures of Eurobonds issued by Russian overseas special purpose vehicles (SPVs). In Panel A, and in Panel B of Tab. 2, we report the main statistics of the number of covenants per issue for the Russian and Eurobond markets, respectively. We obtained this information from Cbonds.ru.

Panel A of Tab. 2 reports the frequency of covenant usage for the initial sample of Russian corporate bonds. The number of covenants on the Russian corporate bond market remains steadily low. Thus, the mean of covenants per issue scarcely reached 1.8 in 2009, and $50 \%$ of the sample debentures have only one covenant clause in the indenture agreement. As a rule, so-called "boiler plate" covenants are included in general terms, but their presence does not play a significant role in restricting corporate financial and investment policy. Between $10 \%$ and $25 \%$ of Russian corporate bond issues do not offer any restrictive covenants. As a result of the volatility in financial markets and a relatively weak institutional environment, direct constraints on an issuer's behaviour are difficult to enforce and are likely to be inefficient ex post. Consequently, firms are likely to desire flexibility, and potential investors are unlikely to value protective covenants.

Interestingly, the results regarding the use of covenants in Eurobonds are strikingly different (Panel B of Tab. 2). The number of covenant clauses in Eurobond indenture 320 agreements varies from 1 to 22 , indicating that all issues of Russian corporate in 
Table 2: Descriptive statistics of the number of covenants for the bond issue in the domestic bond market (Panel A), and in the Eurobond market (Panel B) for all years in the sample.

\begin{tabular}{|c|c|c|c|c|c|c|c|}
\hline \multirow{2}{*}{ Variables } & \multicolumn{6}{|c|}{ Issuance period } & \multirow{2}{*}{ Full sample } \\
\hline & 2008 & 2009 & 2010 & 2011 & 2012 & 2013 & \\
\hline \multicolumn{8}{|c|}{ Panel A: domestic corporate bonds } \\
\hline Mean & 0.8 & 1.8 & 1.8 & 1.1 & 1.5 & 1.2 & 1.35 \\
\hline Min & 0 & 0 & 0 & 0 & 0 & 0 & 0 \\
\hline $10 \%$ percentile & 0 & 0 & 0 & 0 & 0 & 0 & 0 \\
\hline $25 \%$ percentile & 0 & 0 & 1 & 0 & 1 & 1 & 0 \\
\hline $50 \%$ percentile & 1 & 1 & 1 & 1 & 1 & 1 & 1 \\
\hline $75 \%$ percentile & 1 & 3 & 3 & 1 & 3 & 1 & 3 \\
\hline $90 \%$ percentile & 2 & 3 & 3 & 3 & 3 & 3 & 3 \\
\hline $\operatorname{Max}$ & 4 & 9 & 5 & 6 & 6 & 5 & 9 \\
\hline \multicolumn{8}{|c|}{ Panel B: Eurobonds } \\
\hline Mean & 7.7 & 8.0 & 7.8 & 7.8 & 9.5 & 9.7 & 8.67 \\
\hline Min & 1 & 1 & 2 & 1 & 2 & 2 & 1 \\
\hline $10 \%$ percentile & 4 & 1 & 2 & 4 & 4 & 4 & 3 \\
\hline $25 \%$ percentile & 4 & 4 & 4 & 4 & 5 & 4 & 4 \\
\hline $50 \%$ percentile & 9 & 9 & 8 & 8 & 8 & 10 & 8 \\
\hline $75 \%$ percentile & 10 & 10 & 11 & 12 & 13 & 13 & 12 \\
\hline $90 \%$ percentile & 12 & 12 & 14 & 13 & 19 & 16 & 14 \\
\hline $\operatorname{Max}$ & 13 & 22 & 15 & 18 & 20 & 21 & 22 \\
\hline
\end{tabular}

Eurobonds market include at least one covenant in their debt contracts. In this case, the mean per issue fluctuates from 7.7 in 2008 to 9.7 in 2013. Furthermore, 50\% of Eurobond issues contain at least eight covenants. In general, the difference in the level of development between the domestic financial market and the Eurobond market defines financial contracting features, including covenant provisions.

If we look more deeply at the covenant group used in the bond issues for the domestic and Eurobond markets, we find very interesting differences (Tab. 3).

The most used covenants on the Russian domestic market are event-related covenants (rating downgrade to the "below investment grade") or default-related covenants (similar to unrated bonds). The use of such covenant types could be explained by the system of law that protects investors in Russia, i.e., these covenants are obligatory. The inclusion of other types of covenants (financial covenants or restrictions on investment policy) in debentures are rare on the Russian market. However, the use of covenants in the corporate financial policy of Russian companies has become more popular. For instance, the mother company can restrict the debt policy of its subsidiaries or associated companies by setting the covenants to limit debt policy and influence debt capacity.

On the Eurobonds market, the most used covenants are specifying bonding activities covenants and restriction on investment policy covenants. This evidence can be explained, on the one hand, by the different level of information between the two countries, on the other, with the demand for more risk control by bondholders on the Eurobonds market.

\subsection{The firm-year sample}

Because our objective is to examine the relations between corporate financial policy and covenants, we also create a firm-year panel database that matches the Cbonds issue data to issuers' financial data reported in financial statements. We begin by using the initial sample of 654 domestic bond issues and 160 Eurobond issues reported in 
Table 3: Descriptive statistics for the number of covenants in the different covenant groups for issues in the domestic corporate market (Panel A) and in the Eurobonds market (Panel B). The classification of the different covenants in the covenant groups is defined in Tab. A

\begin{tabular}{|c|c|c|c|c|c|}
\hline \multirow{2}{*}{ Covenant group } & \multicolumn{3}{|c|}{ On single issue } & \multicolumn{2}{|c|}{ On all issue } \\
\hline & mean & $\min$ & $\max$ & sum & $\%$ \\
\hline \multicolumn{6}{|l|}{ Panel A: domestic corporate bonds } \\
\hline Restrictions on investment policy & 0.020 & 0 & 1 & 6 & $0.9 \%$ \\
\hline Restrictions on dividend payments & 0.003 & 0 & 1 & 1 & $0.1 \%$ \\
\hline Restriction of financing policy & 0.010 & 0 & 2 & 3 & $0.4 \%$ \\
\hline Default-related covenants & 0.597 & 0 & 3 & 176 & $25.7 \%$ \\
\hline Specifying bonding activities & 0.024 & 0 & 3 & 7 & $1.0 \%$ \\
\hline Event-related covenants & 0.810 & 0 & 3 & 239 & $34.9 \%$ \\
\hline Financial covenants & 0.003 & 0 & 1 & 1 & $0.1 \%$ \\
\hline Total & 1.471 & 0 & 9 & 434 & $100 \%$ \\
\hline \multicolumn{6}{|l|}{ Panel B: Eurobonds } \\
\hline Restrictions on investment policy & 2.494 & 0 & 5 & 192 & $28.0 \%$ \\
\hline Restrictions on dividend payments & 0.312 & 0 & 2 & 24 & $3.5 \%$ \\
\hline Restriction of financing policy & 1.494 & 0 & 6 & 115 & $16.8 \%$ \\
\hline Default-related covenants & 0.623 & 0 & 4 & 48 & $7.0 \%$ \\
\hline Specifying bonding activities & 3.026 & 0 & 10 & 233 & $34.0 \%$ \\
\hline Event-related covenants & 0.610 & 0 & 4 & 47 & $6.9 \%$ \\
\hline Financial covenants & 0.299 & 0 & 4 & 23 & $3.4 \%$ \\
\hline Total & 8.896 & 0 & 22 & 685 & $100 \%$ \\
\hline
\end{tabular}

Tab. 1. Panel A and Panel B, to create a firm-year panel of bond issues. We trace individual bond issues to their issuing firm and then track the firm's portfolio of bond issues over the 2008-2013 period by adjusting issue features (maturity, coupon rate, offering yield, and covenant provisions) to the portfolio. We then match these data to the firm's financial characteristics. Requiring that firms have non-missing values for the dependent and independent variables, we exclude several companies with missing financial reports. The final panel consists of 1,174 firm-year observations of 200 different firms over the period from 2008 to 2013. This sample is unique because detailed information on covenant protection is not publicly available.

Tab. 4 presents the sample distribution by industry used in our analysis. Regarding the number of issuers, the dominant industries are the following: power (the largest issuers: Atomenergoprom, FGC UES, and RusHydro); construction and development 360 (Glavnaya Doroga, LSR Group, and Western High Speed Diameter); and engineering (Borets, OPK Oboronprom, Power Machines, and United Aircraft Corporation). Among 200 firms, 69 have outstanding Eurobonds. Moreover, 54 of them issued Eurobonds during the period of observation, and 29 issuers placed their public debt on both markets.

365 Regarding the different composition of industries that issue in the two markets (see the last column of Tab. 4), the oil and gas and mining industries tend to issue in the Eurobond market, while the power and engineering industries tend to issue in domestic corporate bonds. Regarding the first two industries, we could assume that it could be related to the currency structure of cash flow (operating and investment).

For instance, oil and gas and mining industries tend to have a major portion of total revenue in USD; thus, it is plausible that this industry tends to issue in the Eurobond market to reduce currency risk. 
Table 4: Industry distribution of all firms that issue a bond during the years 2008-2013. E indicates that the firm has issued a bond in the Eurobond market, $\mathrm{R}$ indicates that the firm has issued in the Russian market only. $\mathrm{E} \%-\mathrm{R} \%$ in the last column indicates the relative difference in the composition of the industry in the two different markets.

\begin{tabular}{|c|c|c|c|c|c|c|}
\hline \multirow{2}{*}{ Industry } & \multicolumn{3}{|c|}{ Number of firms } & \multicolumn{3}{|c|}{$\%$ of the total } \\
\hline & $\mathrm{E}$ & $\mathrm{R}$ & Total & $\mathrm{E} \%$ & $\mathrm{R} \%$ & $\mathrm{E} \%-\mathrm{R} \%$ \\
\hline Agriculture & & 5 & 5 & & $3 \%$ & $-3 \%$ \\
\hline Construction materials production & & 5 & 5 & & $3 \%$ & $-3 \%$ \\
\hline Construction and development & 6 & 16 & 22 & $11 \%$ & $11 \%$ & $0 \%$ \\
\hline Mining industry & 6 & 4 & 10 & $11 \%$ & $3 \%$ & $8 \%$ \\
\hline Communication & 4 & 4 & 8 & $7 \%$ & $3 \%$ & $5 \%$ \\
\hline Retail & 1 & 13 & 14 & $2 \%$ & $9 \%$ & $-7 \%$ \\
\hline Transportation & 4 & 10 & 14 & $7 \%$ & $7 \%$ & $1 \%$ \\
\hline Oil and gas service companies & 1 & & 1 & $2 \%$ & & $2 \%$ \\
\hline Textile industry & & 1 & 1 & & $1 \%$ & $-1 \%$ \\
\hline Non-ferrous metals & & 3 & 3 & & $2 \%$ & $-2 \%$ \\
\hline Food industry & 1 & 8 & 9 & $2 \%$ & $5 \%$ & $-4 \%$ \\
\hline Ferrous metals & 5 & 6 & 11 & $9 \%$ & $4 \%$ & $5 \%$ \\
\hline Chemical and petrochemical industry & 6 & 7 & 13 & $11 \%$ & $5 \%$ & $6 \%$ \\
\hline Oil and gas & 10 & 5 & 15 & $19 \%$ & $3 \%$ & $15 \%$ \\
\hline Engineering industry & 2 & 19 & 21 & $4 \%$ & $13 \%$ & $-9 \%$ \\
\hline Other sectors & 6 & 16 & 22 & $11 \%$ & $11 \%$ & $0 \%$ \\
\hline Power & 2 & 24 & 26 & $4 \%$ & $16 \%$ & $-13 \%$ \\
\hline Total & 54 & 146 & 200 & $100 \%$ & $100 \%$ & \\
\hline
\end{tabular}

\subsection{Covenant index and variables}

In order to capture covenant protection, we use a covenant index in our analysis. Index construction has been used as a promising methodology in recent research to capture the strength of the protection of the total covenant set of a bond issue Bradley \& Roberts (2015); Chava et al. (2004); Wei (2005); Billett et al. (2007). One option is to follow the method of Bradley \& Roberts (2015) by counting the number of covenants included in each contract. However, this method ignores the probable correlations among the covenants, suggesting complementary effects between different covenants, especially those from the same type. To partially solve this problem, we implement the method of Billett et al. (2007), where we use seven covenant groups (see Tab. A) to create a firm-year index of covenant protection. We obtain this information from Cbonds.ru, manually analysing the prospectuses of Russian corporate bonds and the indentures of Eurobonds issued by Russian firms. In our preliminary results for an issuing firm in a given year, we begin by creating a variable that equals 1 if at least one bond issue in its debt portfolio has the given type of covenant and zero otherwise. Afterwards, we sum the indicators to create a covenant protection index ${ }^{3}$. By definition, the index ranges between 0 (no covenant protection) and 7 (maximum 390 covenant protection). We assume that all types of covenants are equally important in restricting firm behaviour, and therefore, a higher index value means more covenant protection

\footnotetext{
${ }^{3}$ In Billett et al. (2007), the indicator was divided by the number of covenant groups - seven in our case - in order to scale the index between 0 and 1. Because we retain that a Poisson regression is the best approach in our analysis, we decide to use our indicator without dividing the sum by the number of covenant groups. As a robustness test in Section 6, we use the definition of a covenant index proposed by Billett et al. (2007).

${ }^{4}$ See Wang (2017) about the different restrictiveness in financial covenants.
} 
To test our hypotheses, we define four types of variables: $(i)$ covenant protection variables, (ii) issue-specific variables, (iii) firm-specific variables, and ( $i v)$ market variables (Tab. 5). The definitions and sources of each variable are shown in Tab. C

Table 5: Summary statistics of all variables used in the empirical tests. The definitions and sources of the variables are shown in Tab. C

\begin{tabular}{lccccc}
\hline Variable & $\#$ & Mean & Std. dev. & Min & Max \\
\hline Covenant protection & & & & & \\
Covnum & 360 & 1.8333 & 1.7457 & 0 & 7 \\
CovnumR & 295 & 1.1119 & 0.7939 & 0 & 5 \\
CovnumE & 77 & 4.0390 & 2.0676 & 0 & 7 \\
dummybondR & 1,174 & 0.2512 & 0.4339 & 0 & 1 \\
dummybondE & 1,174 & 0.0655 & 0.2476 & 0 & 1 \\
dummyE & 1,174 & 0.2614 & 0.4396 & 0 & 1 \\
Issue characteristics & & & & & \\
Maturity & 360 & 5.2684 & 3.4259 & 0.3562 & 33.1661 \\
Yield & 360 & 10.0714 & 3.6380 & 0 & 19.3 \\
dummyrating1 & 360 & 0.3833 & 0.4869 & 0 & 1 \\
dummyrating2 & 360 & 0.4528 & 0.4984 & 0 & 1 \\
Firm characteristics & & & & & \\
Leverage & 1,138 & 64.3322 & 32.5752 & 0.0716 & 297.8683 \\
Size & 1,139 & 17.0835 & 2.1105 & 7.6029 & 23.2534 \\
Growth & 912 & 0.1228 & 0.9569 & -7.6634 & 6.7205 \\
Market characteristics & & & & & \\
Creditspread & 6 & 3.5643 & 2.0383 & 1.9164 & 6.9652 \\
GDP & 6 & 101.8333 & 4.4716 & 92.2 & 105.2 \\
MICEX & 6 & $1,346.66$ & 336.40 & 619.53 & 1687.99 \\
\hline
\end{tabular}

The first group of variables consists of three covenant indexes, one for all issues (Covnum), one for Russian issues only (CovnumR), one for Eurobond issues only (CovnumE), and three dummy variables. DummybondR and DummybondE are dummy variables that are set to 1 if a firm places bonds on the Russian domestic 400 or Eurobond markets, respectively, and 0 otherwise. Additionally, we use DummyE, which takes the value of 1 if a firm experienced Eurobond placement (i.e., a firm has outstanding Eurobonds) and 0 otherwise.

The second group of variables consists of two bond-specific factors: Maturity and Yield, and the rating of the issue. Maturity measures the weighted average matu-

405 rity in the years of a firm's bond portfolio issued in a certain year. The choice of debt contract terms including maturity and covenant provisions can be used to reduce adverse selection and moral hazard costs or to signal a firm's quality when information asymmetry about its future prospects exists. In highly asymmetric information environments, firms favour the issuance of short-term debt or debt with protective 410 covenants because such provisions promote a reduction in agency costs. To this extent, we expect short-term debt and covenant clauses to substitute for one another, and therefore, the coefficient of maturity is predicted to be positive. As a proxy for the cost of debt, we use Yield, the weighted average nominal yield to maturity of a firm's bond portfolio issued in a certain year obtained from the Cbond database.

415 Because shareholder-bondholder conflicts are more severe when debt is risky and because liquidity risk is more important for lower-quality firms, we might expect that the likelihood of financial distress affects the offering yield of bonds. We use issuer credit ratings as a proxy for financial distress risk. We focus on Moody's and S\&P credit ratings. We structure the rating using two different dummies regarding the more risky 
position only in the following way: $(i)$ below investment grade (dummyrating1) bonds with credit ratings less than $\mathrm{BB}+(\mathrm{Ba} 1)$ - and (ii) bonds with no ratings or withdrawn international ratings (dummyrating 2 ).

Regarding firm-specific factors, we include three proxies as characteristics of issuers' risk profiles (leverage, size, and growth opportunity). We compute all variables the basis of firms' financial statements, which were taken from the information disclosure system Interfax. Highly leveraged firms have a greater incentive for riskshifting behaviour. In order to test the predicted interdependency between borrowers' financial risk and protective covenants, we use Leverage, the ratio of the firm's total debt to the firm's book value of assets, like Bradley \& Roberts (2015), Paglia \&

430 Mullineaux (2006), and Park et al. (2013). Nevertheless, an extensive body of empirical research (Billett et al., 2007, Correia, 2008; Frankel et al., 2008) computes the proxy for financial leverage as the total debt divided by the book (or market) value of equity. We focus on the first method mainly because certain firms in our panel have accumulated losses from prior years, which, according to accounting standards,

435 provide negative equity in their balance sheets. To overcome the problem of a negative sign for leverage, total assets instead of equity are used as the denominator for leverage. Additionally, in order to achieve the goal of finding evidence of a relation between covenant protection and a firm's risk profile, we compute the firm's size (Size) and growth opportunity (Growth). Conventional wisdom on measuring a firm's size from

440 empirical evidence of the agency theory of covenants is to use the log of the market cap as a proxy (Nash et al., 2003; Adam \& Goyal, 2008: Bradley \& Roberts, 2015). In consideration of the fact that a significant number of companies on our panel are not publicly traded companies and their shares do not have a public market price, we choose to determine the issuer's size as a logarithm of the firm's book value of assets. For the same reason, we evaluate growth opportunity with a backward-looking measure of sales growth computed as $\log$ Sales $_{t}-\log$ Sales $_{t-1}$ using the natural logarithm of sales revenue in years $t$ and $t-1$. Finally, to control for systemic credit risk, we compute credit spread (Creditspread) as the difference in yield between corporate bonds and a risk-free credit benchmark, in our case, Russian government bonds (OFZ). To control for aggregate economic conditions, we use gross domestic product index $(G D P)$ and a capitalisation-weighted composite index $(M I C E X)$.

\section{Methodology}

The hypotheses of the study are are tested using regression models. In particular, hypotheses 1 and 2 assume covenant protection as the dependent variable, as measured by the sum of different covenants related to bond issues and has the nature of a count outcome. Under these conditions, Poisson regression models are the appropriate tool to use. Moreover, the data fit the assumptions behind this model quite well, namely, no overdispersion - the range of variation in the count outcome is limited; in our case, it ranges from 0 to 7 and a "reasonable" percentage of "zeros" is around $20 \%$. In the Poisson regression model, the response $Y$ - the covenant protection count in our case - has a Poisson distribution: $y_{i} \sim \operatorname{Poisson}(\mu)$ for $i=1, \ldots, N$ and the expected count of $y_{i}$ is given by $E(Y)=\mu$. The parameter $\mu$ is a measure of the intensity of the phenomenon. The regression model begins by defining the probability of observing $y$ occurrences of the variable $Y$, which, in this context, is defined as the number of different covenants issued on a bond by a firm $\left(C P_{i, t}\right)$ as a function of $\mu$, as in the 
following:

$$
\operatorname{Pr}\left(C P_{i, t}=y\right)=\frac{e^{-\mu} \mu^{y}}{y !}
$$

for $y=0,1,2, \ldots$ To characterise the model, we must parametrise it using a set of independent variables $\left(\mathbf{x}_{i t}\right)$ :

$$
\mu_{i t}=\exp \left(\mathbf{x}_{i t}^{\prime} \beta\right)
$$

for $i=1,2, \ldots, N$. The models are estimated using the maximum likelihood estimator that ensures consistent estimations of the parameters. Hypothesis 3 is tested using linear regression models estimated through OLS.

In all the models, we pooled the data across years for individual firms. The nature of the data allowed heteroskedasticity to occur in the models as a result of the dependence of individual observations across time. That is, the observations are independent across groups (clusters) but not necessarily within groups. Hence, the inference is based on a matrix of variance and covariance that allows for intragroup correlations, relaxing the usual requirement of i.i.d. observations, i.e., we used within-firm cluster standard error adjustment: 5

Hypothesis 1 tests the relationship between the use of covenants as protection against the risk of the issue. As discussed in Sect. 2 we identify the three most important sources of risk in a bond issue: $(i)$ Maturity is the maturity of the bonds in years, (ii) Size is the natural logarithm of the assets of the firm, and (iii) Growth is the time difference in the natural logarithm of the sales. Considering Eq. (2), we parametrise the model as follows:

$$
\mu_{i t}=C P_{i, t}=\exp \left(\beta^{\prime} R I S K_{i, t}+\gamma^{\prime} X_{i, t}+\sum_{s=2}^{5} \varphi_{s} \times \text { sector }_{s}\right)
$$

for $i=1,2, \ldots, N$.

Hypothesis 2 tests the impact of issuing a bond in the Eurobond market on covenant protection in the Russian market using the following model:

$$
\mu_{i t}=C P_{i, t}=\exp \left(\beta^{\prime} C P E_{i, t}+\gamma^{\prime} X_{i, t}+\sum_{s=2}^{5} \varphi_{s} \times \text { sector }_{s}\right)
$$

where we use two different independent variables for covenant protection in the Eurobond market $(C P E)$ : CovnumE, a covenant index for Eurobond issuers, and a dummy (dummybondE) if the firm has outstanding Eurobonds. We test the model using two different specifications of the dependent variable covenant protection $(C P)$ : a covenant index for all of the issues (Covnum) and one for Russian issues only (CovnumR).

With the third hypothesis, we test the cost-contracting hypothesis of Smith Jr \& Warner (1979). The two authors argue that because covenant restrictions are costly to a firm, they must confer some benefit in the reduction of agency costs, which translates

${ }^{5}$ Note that we do not use the Huber/White/sandwich estimator of variance proposed by White (1980) for our baseline specification, given that it is unable to relax the assumption of the independence of the observations. Instead, we used a different version of a robust estimator that allows for a block covariance matrix of errors, where each block refers to a single firm. 
into a lower cost of debt. This result has been found in some recent empirical papers (Reisel, 2014, Chava et al., 2010, Wei, 2005). We test the following model:

$$
\text { Yield }_{i, t}=\alpha+\beta^{\prime} C P_{i, t}+\gamma^{\prime} X_{i, t}+\sum_{s=2}^{5} \varphi_{s} \times \text { sector }_{s}+\varepsilon_{i, t}
$$

where we use three specifications for covenant protection $C P$ : covenant protection for all bond issues (Covnum), covenant protection for Russian issues (CovnumR) and covenant protection for Eurobond issues (CovnumE).

We do not investigate another interesting aspect of Russian firms' decision regarding in which bond market be active. The topic is worth noting, but given its complexity, it seems to be beyond the scope of the paper. For the sake of clarity, please note that this aspect could determine a selection bias, namely, that firms that make different decisions could be different. Eventually, this bias could also bias the results. Nonetheless, if the observable characteristics define different "types" of firms, then the explanatory variables introduced in the estimated models should at least capture part of this eventual selection bias, allowing us to make inferences from the estimated coefficients.

\section{Results}

Regarding hypothesis 1 , the empirical results are shown in Tab. 66 The Wald Chi-test leads us to reject the null hypothesis of jointly null coefficients.

The sign of the Maturity variable is as expected: as maturity increases, the risk of the bond increases and the covenant protection by the market increases, but the sign of the size variable in the second specification contradicts previous results in the literature (Malitz, 1986, Nash et al., 2003, Bradley \& Roberts, 2015). Assuming that larger firms have more debt offerings, they are more likely to include covenants that can reduce risk and make the bonds more attractive to investors. Moreover, due to a lack of variety in the types of covenants used in the Russian financial market and the weak institutional environment, we suppose that large firms could have incentives to offer more covenant protection to their bondholders without significantly restricting their ability to make future investment and financial decisions. This supposition is also consistent with the evidence provided by Niskanen \& Niskanen (2004) that large firms are more likely to have covenants in their loan contracts. Furthermore, the authors examine the use and determinants of covenants in Finnish corporate loans, which are defined by weak covenant protection (only 72 out of 642 loans include at least one covenant), as well as the Russian domestic bond market. Additionally, the low level of external investor protection in the Russian institutional framework accompanied by developing internal corporate governance in large companies encourages them to include covenant protection in their indenture agreements, which is impor-

525 tant in situations of uncertainty and high volatility in financial markets. Regarding the control variables, the significance of dummybondE in both specifications indicates that issuance in the Eurobond market has an important role in determining covenant protection. We will analyse this aspect in more detail in the following hypothesis.

The empirical results of hypothesis 2 are shown in Tab. 7. Again, in this case, the 530 Wald Chi-test leads us to reject the null hypothesis of jointly null coefficients.

The positive coefficient of CovnumE in specification (1) seems to indicate that bondholders in general ask for more covenant protection in domestic bond market in order to compensate for the different creditor protections between Russian law and law 
Table 6: Poisson regressions with clustered standard errors regarding the relation between covenant protection and risk (Hypothesis 1). Specification (1) regards the firms that issue a bond in the sample period. Specification (2) regards the firms that issue a bond in the Russian market in the sample period. All variables are defined in Tab. C Robust standard errors in parentheses. ***, **, and * denote significance at the $1 \%, 5 \%$, and $10 \%$ levels, respectively. Control for Sector (see Tab. B as indicated.

\begin{tabular}{|c|c|c|}
\hline Dependent variable & $\begin{array}{c}(1) \\
\text { Covnum }\end{array}$ & $\begin{array}{c}(2) \\
\text { CovnumR }\end{array}$ \\
\hline \multicolumn{3}{|l|}{ Independent variables } \\
\hline Maturity & $\begin{array}{c}0.0297^{* * *} \\
(0.012)\end{array}$ & $\begin{array}{c}0.0309^{* *} \\
(0.013)\end{array}$ \\
\hline Size $_{t-1}$ & $\begin{array}{c}0.0417 \\
(0.028)\end{array}$ & $\begin{array}{c}0.0975^{* * *} * \\
(0.032)\end{array}$ \\
\hline Growth & $\begin{array}{l}0.0249 \\
(0.033)\end{array}$ & $\begin{array}{c}0.0843^{* *} \\
(0.037)\end{array}$ \\
\hline $\begin{array}{l}\text { Control variables } \\
\text { dummybondE }\end{array}$ & $\begin{array}{c}1.1111^{* * *} \\
(0.098)\end{array}$ & $\begin{array}{c}0.3119^{* * * *} \\
(0.118)\end{array}$ \\
\hline Leverage $_{t-1}$ & $\begin{array}{c}0.0021 \\
(0.001)\end{array}$ & $\begin{array}{c}0.0027^{* *} \\
(0.001)\end{array}$ \\
\hline dummyrating1 & $\begin{array}{l}0.1209 \\
(0.122)\end{array}$ & $\begin{array}{l}0.2651^{*} \\
(0.149)\end{array}$ \\
\hline dummyrating2 & $\begin{array}{c}-0.1970 \\
(0.158)\end{array}$ & $\begin{array}{l}0.1662 \\
(0.190)\end{array}$ \\
\hline Creditspread & $\begin{array}{l}0.0365 \\
(0.050)\end{array}$ & $\begin{array}{c}0.1832^{* *} \\
(0.073)\end{array}$ \\
\hline MICEX & $\begin{array}{r}-0.0002 \\
(0.000)\end{array}$ & $\begin{array}{l}0.0003 \\
(0.000)\end{array}$ \\
\hline GDP & $\begin{array}{l}0.0021 \\
(0.022)\end{array}$ & $\begin{array}{c}0.0535^{*} \\
(0.031)\end{array}$ \\
\hline Sector & Yes & Yes \\
\hline Constant & $\begin{array}{l}-0.6995 \\
(2.453)\end{array}$ & $\begin{array}{c}-8.3565^{* *} \\
(3.285)\end{array}$ \\
\hline Observations & 299 & 248 \\
\hline Pseudo $R^{2}$ & 0.216 & 0.0318 \\
\hline Wald Chi-test & $\begin{array}{c}337.3 \\
(0.000)\end{array}$ & $\begin{array}{c}58.53 \\
(0.000)\end{array}$ \\
\hline
\end{tabular}

in the United Kingdom. This result can be partially derived from the construction of

the Covnum in cases of contemporaneous issues in the Russian and Eurobond markets, indicating higher protection in the Euro market compared to the domestic market. If we look at the results in the remaining two specifications, columns (2) and (3), in which we eliminate the influences of index construction and of the different values of protection in the two markets, the result will be confirmed. If a firm has outstanding 540 Eurobonds (dummyE), the covenant protection required for an issue in the Russian market will be higher than that for a firm without outstanding Eurobonds. This effect will be greater if the firm issues contemporaneously in the two markets, as indicated by the coefficient of dummybondE in specification (3).

These results seem to confirm hypothesis 2. Russian bondholders ask for more covenant protection than bondholders in the Eurobond market in order to have the same creditor rights. In other words, Russian bondholders compensate for the differences in creditor protection - measured by creditor protection index, equal to 4 for the United Kingdom and 1.8 for Russia (?) — by increasing protection given by covenants. In fact, the only possibility for Russian bondholders to have the same creditor rights is to increase the covenant protections for domestic issues. Regarding the control vari- 
Table 7: Poisson regressions with clustered standard errors regarding the relation between covenant protection in the Eurobond market and covenant protection in the Russian market (Hypothesis 2). Specification (1) regards firms that issue a bond in the sample period. Specifications (2) and (3) regard firms that issue a bond in the Russian market in the sample period. All variables are defined in Tab. C Robust standard errors in parentheses. ***,**, and * denote significance at the 1\%, 5\%, and $10 \%$ levels, respectively. Control for Sector (see Tab. B as indicated.

\begin{tabular}{|c|c|c|c|}
\hline Dependent variable & $\begin{array}{c}(1) \\
\text { Covnum }\end{array}$ & $\begin{array}{c}(2) \\
\text { CovnumR }\end{array}$ & $\begin{array}{c}(3) \\
\text { CovnumR }\end{array}$ \\
\hline \multicolumn{4}{|l|}{ Independent variables } \\
\hline CovnumE & $\begin{array}{c}0.2708^{* * *} \\
(0.011)\end{array}$ & & \\
\hline dummyE & & $\begin{array}{c}0.2554^{*} \\
(0.135)\end{array}$ & \\
\hline dummybondE & & & $\begin{array}{c}0.3119^{* * * *} \\
(0.118)\end{array}$ \\
\hline \multicolumn{4}{|l|}{ Control variables } \\
\hline Maturity & $\begin{array}{c}0.0206^{* *} \\
(0.009)\end{array}$ & $\begin{array}{c}0.0252^{* *} \\
(0.013)\end{array}$ & $\begin{array}{c}0.0309 * * \\
(0.013)\end{array}$ \\
\hline Leverage $_{t-1}$ & $\begin{array}{c}0.0020^{* *} \\
(0.001)\end{array}$ & $\begin{array}{c}0.0030^{* *} \\
(0.001)\end{array}$ & $\begin{array}{c}0.0027^{* *} \\
(0.001)\end{array}$ \\
\hline $\operatorname{Size}_{t-1}$ & $\begin{array}{c}0.0554^{* * *} \\
(0.019)\end{array}$ & $\begin{array}{c}0.0779 * * \\
(0.033)\end{array}$ & $\begin{array}{c}0.0975^{* * * *} \\
(0.032)\end{array}$ \\
\hline Growth & $\begin{array}{c}0.0513^{* *} \\
(0.026)\end{array}$ & $\begin{array}{c}0.0848^{* *} \\
(0.034)\end{array}$ & $\begin{array}{c}0.0843^{* *} \\
(0.037)\end{array}$ \\
\hline dummyrating 1 & $\begin{array}{l}0.1001 \\
(0.066)\end{array}$ & $\begin{array}{c}0.2766^{*} \\
(0.147)\end{array}$ & $\begin{array}{c}0.2651^{*} \\
(0.149)\end{array}$ \\
\hline dummyrating2 & $\begin{array}{r}-0.0022 \\
(0.109)\end{array}$ & $\begin{array}{l}0.1809 \\
(0.184)\end{array}$ & $\begin{array}{l}0.1662 \\
(0.190)\end{array}$ \\
\hline Creditspread & $\begin{array}{c}0.0543^{*} \\
(0.030)\end{array}$ & $\begin{array}{c}0.1645^{* *} \\
(0.073)\end{array}$ & $\begin{array}{c}0.1832^{* *} \\
(0.073)\end{array}$ \\
\hline MICEX & $\begin{array}{l}0.0002 \\
(0.000)\end{array}$ & $\begin{array}{l}0.0002 \\
(0.000)\end{array}$ & $\begin{array}{l}0.0003 \\
(0.000)\end{array}$ \\
\hline GDP & $\begin{array}{l}0.0080 \\
(0.013)\end{array}$ & $\begin{array}{l}0.0478 \\
(0.030)\end{array}$ & $\begin{array}{c}0.0535^{*} \\
(0.031)\end{array}$ \\
\hline Sector & Yes & Yes & Yes \\
\hline Constant & $\begin{array}{c}-2.2531^{*} \\
(1.349)\end{array}$ & $\begin{array}{c}-7.3838^{* *} \\
(3.282)\end{array}$ & $\begin{array}{c}-8.3565^{* *} \\
(3.285)\end{array}$ \\
\hline Observations & 299 & 248 & 248 \\
\hline Pseudo $R^{2}$ & 0.288 & 0.0345 & 0.0318 \\
\hline Wald Chi-test & $\begin{array}{c}975.6 \\
(0.000)\end{array}$ & $\begin{array}{c}52.95 \\
(0.000)\end{array}$ & $\begin{array}{c}58.53 \\
(0.000)\end{array}$ \\
\hline
\end{tabular}

ables, the result we obtain for the rating is consistent with the theoretical literature on covenant protection. If a firm's rating is below investment grade (dummyrating 1 ), the level of protection must be higher.

The empirical results of the test of hypothesis 3 are shown in Tab. 8 . The $F$-test leads us to reject the null hypothesis of jointly null coefficients, and the values of corrected $R^{2}$ confirm that the explanatory power of the models is good. The signs we obtain are as expected. As the covenant protection increases, the overall cost of debt for the firm decreases, as indicated by the negative signs of Covnum in column (1) and of CovnumE in column (3). This result is consistent with the $\mathrm{CCH}$ and the available empirical examination of the agency cost approach. This result seems to be absent from the Russian market, as indicated by the lack of significance of the variable CovnumR in column (2). Regarding the control variables, the signs we found are as expected. Size (Size) has a negative impact on the cost of debt (but not on the risk, as 
Table 8: OLS regressions with clustered standard errors regarding the relation between yield and covenant protection (Hypothesis 3). Specifications (1), (3), and (4) regard the firms that issue a bond in the sample period. Specification (2) regards the firms that issue a bond in Russian market only in the sample period. All variables are defined in Tab. C Robust standard errors in parentheses. ***, $* *$, and $*$ denote significance at the $1 \%, 5 \%$, and $10 \%$ levels, respectively. Control for Sector (see Tab. B as indicated.

\begin{tabular}{|c|c|c|c|c|}
\hline Dependent variable & $\begin{array}{c}(1) \\
\text { yield }\end{array}$ & $\begin{array}{c}(2) \\
\text { yield }(\mathrm{R})\end{array}$ & $\begin{array}{c}(3) \\
\text { yield }\end{array}$ & $\begin{array}{c}(4) \\
\text { yield }\end{array}$ \\
\hline \multicolumn{5}{|l|}{ Independent variables } \\
\hline Covnum & $\begin{array}{c}-0.6007^{* * *} \\
(0.107)\end{array}$ & & & \\
\hline CovnumR & & $\begin{array}{r}-0.0572 \\
(0.178)\end{array}$ & & \\
\hline CovnumE & & & $\begin{array}{c}-0.5993^{* * *} \\
(0.093)\end{array}$ & $\begin{array}{c}-0.2034^{*} \\
(0.113)\end{array}$ \\
\hline dummybondE & & & & $\begin{array}{c}-2.4739 * * * \\
(0.587)\end{array}$ \\
\hline \multicolumn{5}{|l|}{ Control variables } \\
\hline Maturity & $\begin{array}{l}0.0135 \\
(0.044)\end{array}$ & $\begin{array}{c}-0.0639^{*} \\
(0.038)\end{array}$ & $\begin{array}{c}-0.0068 \\
(0.045)\end{array}$ & $\begin{array}{c}-0.0210 \\
(0.040)\end{array}$ \\
\hline Leverage $_{t-1}$ & $\begin{array}{l}0.0086 \\
(0.007)\end{array}$ & $\begin{array}{c}0.0129^{* *} \\
(0.006)\end{array}$ & $\begin{array}{l}0.0085 \\
(0.006)\end{array}$ & $\begin{array}{l}0.0089 \\
(0.006)\end{array}$ \\
\hline $\operatorname{Size}_{t-1}$ & $\begin{array}{c}-0.3336 * * * \\
(0.109)\end{array}$ & $\begin{array}{c}-0.2888^{* *} \\
(0.113)\end{array}$ & $\begin{array}{c}-0.3664^{* * *} \\
(0.106)\end{array}$ & $\begin{array}{c}-0.3775^{* * *} \\
(0.104)\end{array}$ \\
\hline Growth & $\begin{array}{c}-0.0004 \\
(0.187)\end{array}$ & $\begin{array}{l}0.0073 \\
(0.240)\end{array}$ & $\begin{array}{c}-0.0805 \\
(0.187)\end{array}$ & $\begin{array}{c}-0.0878 \\
(0.187)\end{array}$ \\
\hline dummyrating1 & $\begin{array}{l}0.5595 \\
(0.402)\end{array}$ & $\begin{array}{l}0.4567 \\
(0.334)\end{array}$ & $\begin{array}{l}0.2674 \\
(0.387)\end{array}$ & $\begin{array}{l}0.2589 \\
(0.375)\end{array}$ \\
\hline dummyrating2 & $\begin{array}{c}1.1424^{* *} \\
(0.547)\end{array}$ & $\begin{array}{c}1.2839^{* * *} \\
(0.419)\end{array}$ & $\begin{array}{l}0.7649 \\
(0.532)\end{array}$ & $\begin{array}{l}0.7150 \\
(0.519)\end{array}$ \\
\hline Creditspread & $\begin{array}{c}0.6159 * * * \\
(0.194)\end{array}$ & $\begin{array}{c}0.3698^{*} \\
(0.195)\end{array}$ & $\begin{array}{c}0.4965^{* *} \\
(0.191)\end{array}$ & $\begin{array}{c}0.4491^{* *} \\
(0.186)\end{array}$ \\
\hline MICEX & $\begin{array}{l}0.0010 \\
(0.001)\end{array}$ & $\begin{array}{l}0.0011 \\
(0.001)\end{array}$ & $\begin{array}{l}0.0009 \\
(0.001)\end{array}$ & $\begin{array}{l}0.0014 \\
(0.001)\end{array}$ \\
\hline GDP & $\begin{array}{c}-0.1813^{* *} \\
(0.076)\end{array}$ & $\begin{array}{c}-0.3402^{* * *} \\
(0.082)\end{array}$ & $\begin{array}{c}-0.2173^{* * *} \\
(0.074)\end{array}$ & $\begin{array}{c}-0.2412^{* * *} \\
(0.072)\end{array}$ \\
\hline Sector & Yes & Yes & Yes & Yes \\
\hline Constant & $\begin{array}{c}31.1574^{* * * *} \\
(8.281)\end{array}$ & $\begin{array}{c}46.4804^{* * *} \\
(8.870)\end{array}$ & $\begin{array}{c}35.6325^{* * *} \\
(8.026)\end{array}$ & $\begin{array}{c}37.7583^{* * *} \\
(7.628)\end{array}$ \\
\hline Observations & 299 & 237 & 299 & 299 \\
\hline$R^{2}$ & 0.584 & 0.657 & 0.608 & 0.632 \\
\hline$F$-test & $\begin{array}{c}35.39 \\
(0.000)\end{array}$ & $\begin{array}{c}30.98 \\
(0.000)\end{array}$ & $\begin{array}{c}32.62 \\
(0.000)\end{array}$ & $\begin{array}{c}33.12 \\
(0.000)\end{array}$ \\
\hline
\end{tabular}

in the first and second hypotheses). If the firm is not rated or if a rating is withdrawn (dummyrating2), the yield will be higher.

The non-significance of the variable CovnumR in column (2), together with the importance of the absence of the rating for increasing the cost of debt for Russian issues, seems to be consistent with the outcomes of the studies by Zhang \& Zhou (2015) and Tanigawa \& Katsura (2013). In both papers, the authors register that the effect of covenants on yield differs for bonds with different credit ratings. Thus, average yield spreads are smaller when the protective power is stronger within investment-grade bond classes. However, if the firm is not rated, protective power does not conform to the average yield spread.

An interesting aspect is highlighted if we compare specification (3) and specification 575 (4) in Tab. 8, where we add to the independent variables the dummy dummybondE, 
which indicates that the firm issues a bond in the Eurobond market. The comparison between the two values, which are both negative and significant but with different dimensions, indicates that the issue of a Eurobond has a positive impact on reducing the financing cost for a Russian firm, and this impact is greater and more important with respect to the impact of Eurobond covenant protection. It seems that bondholders perceive a Russian firm that has decided to issue in the Eurobond market as less risky.

\section{Robustness checks}

Because in the empirical literature on covenant protection, the most common used analysis is conducted by OLS regression using as a covenant protection index such as that proposed by Billett et al. (2007), we decide to use this method in our robustness checks for all the three hypotheses presented. For this reason, we construct three indexes of covenant protection by dividing the previous index by 7 , i.e.,

$$
\begin{aligned}
\text { Covindex }_{i, t} & =\text { Covnum }_{i, t} / 7 \\
\text { Covindex }_{i, t} & =\text { Covnum }_{i, t} / 7 \\
{\text { Covindex } E_{i, t}} & =\text { Covnum }_{i, t} / 7
\end{aligned}
$$

Tab. 9 presents the results of the robustness checks proposed using the OLS specisecond, by re-running our estimations. For each firm that issued a bond, we randomly draw a covenant protection index from the set of actual covenant protection indices. In a sense, we re-shuffle the distribution of covenant protection indices across firms. Then,

${ }_{600}$ using these pseudo-covenant protection rates, we re-estimate our regressions. The idea behind the exercise is that if covenant protection is randomly assigned to firms, then we should expect that all determinants of covenant protection that we introduced for hypothesis 1 should not play a role, i.e., the related estimated coefficients should turn out to be non-significant in the vast majority of the cases. If this is true, then 605 this indirectly lends support to our regression model results because we can interpret significant coefficients in regressions as proof of the existence of causal nexus - from explanatory variables to covenant protection intensity - and not only as the effect of chance. Indeed, in the latter case, we should get non-significant results, as explained above. We repeat this exercise 200 times and obtain the distribution of the pseudo ${ }_{610}$ coefficient on the regressions together with the percentage of significant coefficients for each independent variable.

The Poisson regression model used to conduct the placebo tests is similar to that used in Tab. 6, and we used the same maximum likelihood estimation method. Tab. 10 
Table 9: OLS regressions regarding the relation between covenant protection and risk (Hypothesis 1). Specification (1) regards the firms that issue a bond in the sample period, and specification (2) regards the firms that issue a bond in the Russian market. All variables are defined in Tab. C Standard errors in parentheses. $* * *, * *$, and $*$ denote significance at the $1 \%, 5 \%$, and $10 \%$ levels, respectively. Control for Sector (see Tab. B] as indicated.

\begin{tabular}{|c|c|c|}
\hline Dependent variable & $\begin{array}{c}(1) \\
\text { Covindex }\end{array}$ & $\begin{array}{c}(2) \\
\text { CovindexR }\end{array}$ \\
\hline \multicolumn{3}{|l|}{ Independent variables } \\
\hline Maturity & $\begin{array}{c}0.0073^{* *} \\
(0.003)\end{array}$ & $\begin{array}{c}0.0054^{* *} \\
(0.002)\end{array}$ \\
\hline $\operatorname{Size}_{t-1}$ & $\begin{array}{l}0.0094 \\
(0.007)\end{array}$ & $\begin{array}{c}0.0142^{* * *} \\
(0.005)\end{array}$ \\
\hline Growth & $\begin{array}{l}0.0031 \\
(0.008)\end{array}$ & $\begin{array}{c}0.0110^{* *} \\
(0.005)\end{array}$ \\
\hline $\begin{array}{l}\text { Control variables } \\
\text { dummybondE }\end{array}$ & $\begin{array}{c}0.4201^{* * *} \\
(0.044)\end{array}$ & $\begin{array}{c}0.0612^{* *} \\
(0.024)\end{array}$ \\
\hline Leverage $_{t-1}$ & $\begin{array}{l}0.0005 \\
(0.000)\end{array}$ & $\begin{array}{c}0.0004^{*} \\
(0.000)\end{array}$ \\
\hline dummyrating1 & $\begin{array}{l}0.0243 \\
(0.038)\end{array}$ & $\begin{array}{l}0.0400 \\
(0.025)\end{array}$ \\
\hline dummyrating2 & $\begin{array}{c}-0.0445 \\
(0.040)\end{array}$ & $\begin{array}{l}0.0238 \\
(0.031)\end{array}$ \\
\hline Creditspread & $\begin{array}{l}0.0067 \\
(0.016)\end{array}$ & $\begin{array}{c}0.0277^{* *} \\
(0.012)\end{array}$ \\
\hline MICEX & $\begin{array}{r}-0.0001 \\
(0.000)\end{array}$ & $\begin{array}{l}0.0001 \\
(0.000)\end{array}$ \\
\hline GDP & $\begin{array}{l}0.0006 \\
(0.007)\end{array}$ & $\begin{array}{l}0.0079 \\
(0.005)\end{array}$ \\
\hline $\begin{array}{l}\text { Sector } \\
\text { Constant }\end{array}$ & $\begin{array}{c}\text { Yes } \\
0.0568 \\
(0.755)\end{array}$ & $\begin{array}{c}\text { Yes } \\
-1.0995^{* *} \\
(0.521)\end{array}$ \\
\hline $\begin{array}{l}\text { Observations } \\
R^{2} \\
F \text {-test }\end{array}$ & $\begin{array}{c}299 \\
0.592 \\
20.05 \\
(0.000)\end{array}$ & $\begin{array}{c}248 \\
0.147 \\
4.689 \\
(0.001)\end{array}$ \\
\hline
\end{tabular}

reports the results of the placebo tests for Hypothesis 1. In particular, the table shows the number of times every independent and control variable coefficient is significant at the $5 \%$ level.

The results for both specifications (1) and (2) confirm the robustness of our results. In fact, all the percentages of significant coefficients are low, indicating the scarce fitness of the model once we re-shuffle the covenant protection across firms.

Regarding hypothesis 2, the OLS model results (Tab. 11) confirm the robustness of our estimations, and the $F$-test rejects the hypothesis of jointly null coefficients. The first model in column (1), which relates to the investigation of the relationship between Covindex $R$ and CovindexE confirms the main result: a positive and significant correlation between the two variables. The sign and significance of the control variables remain consistent with the results in Tab. 7. The second model in column (2) also confirms the positive relationship between Covindex $R$ and dummyE. The sign and significance of the control variables are consistent with the main results. The last model in column (3) shows that an issue in the Eurobon market counts as a determinant of the number of covenants used on bonds, as measured by the vari${ }_{630}$ able CovindexR. In this case, the control variables again maintain their sign and 
Table 10: Placebo tests regarding the relation between covenant protection and risk (Hypothesis 1). Specification (1) regards the firms that issue a bond in the sample period, and specification (2) regards the firms that issue a bond in the Russian market. The value shows the percentage of coefficients of independent and control variables are significantly different from zero at $5 \%$ over 200 simulations. All variables are defined in Tab. C

\begin{tabular}{lcc}
\hline Dependent variable & $\begin{array}{c}(1) \\
\text { Covnum }\end{array}$ & $\begin{array}{c}(2) \\
\text { CovnumR }\end{array}$ \\
\hline Independent variables & & \\
Maturity & $3 \%$ & $4 \%$ \\
Size $_{t-1}$ & $4 \%$ & $3.5 \%$ \\
Growth & $3.5 \%$ & $5.5 \%$ \\
Control variables & & \\
dummybondE & $3.5 \%$ & $3.5 \%$ \\
Leverage $t-1$ & $5 \%$ & $7 \%$ \\
dummyrating1 & $3 \%$ & $2.5 \%$ \\
dummyrating2 & $4 \%$ & $3.5 \%$ \\
Creditspread & $2.5 \%$ & $2.5 \%$ \\
MICEX & $2.5 \%$ & $1.5 \%$ \\
GDP & $2 \%$ & $0 \%$ \\
\hline
\end{tabular}

significance, consistent with the results in Tab. 7 .

In the case of hypothesis 2 , we conduct a set of placebo tests: we randomly reassigned covenant protection index across firms (in this case, Covnum and CovnumR) and then run the Poisson regression model, similar to that in Tab. 7. The tests are similar to those described for hypothesis 1 above. The results of the placebo test are shown in Tab. 12. Additionally, in this case, the low value of the percentage of significant coefficients lends support to our assumption.

Finally, Tab. 13 reports the main results of the robustness checks of the evidence proposed in Tab. 8 about the empirical validation of hypothesis 3. First, we use as independent variables the covenant protection index proposed by Billett et al. (2007), i.e., we substitute Covnum, CovnumR, and CovnumE with the correspondent Covindex, CovindexR, and CovindexE. We also replace the variable $G D P$ with a control for the year (Year). The results in the fourth column indicate no change in sign and significance of the independent variables and of the control variables, which remain consistent with the results in Tab. 8 ,

\section{Conclusion}

The conflict of interest between bondholders and shareholders results in actions undertaken by managers that have a negative impact on firm value. One way to mitigate these conflicts is to include appropriate covenants in debt contracts.

Using a hand-collected database of Russian firms that issue bonds in both the domestic and Eurobond markets, we test three hypotheses. First, we find, as expected, that as the risk of the issue for both bond and firm characteristics increases, covenant protection increases. We also verify that covenant protection in a domestic issue is higher for a firm that has Eurobonds in its debt portfolio in order to compensate for the different levels of creditor protection. With the third hypothesis, we find, as expected, a negative relation between the overall cost of a bond and its covenant protection, and this effect is more significant if the firm has issued Eurobonds.

These results suggest several policy implications. First, Russian firms should issue more in the Eurobond market because they can obtain significant benefits with 
Table 11: OLS results regarding the relation between covenant protection in the Eurobond market and covenant protection in the Russian market (Hypothesis 2). Specification (1) regards the firms that issue a bond in the sample period, and specifications (2) and (3) regard the firms that issue a bond in Russian market. All variables are defined in Tab. C Standard errors in parentheses. ***, $* *$, and $*$ denote significance at the $1 \%, 5 \%$, and $10 \%$ levels, respectively. Control for Sector (see Tab. B] as indicated.

\begin{tabular}{|c|c|c|c|}
\hline Dependent variable & $\begin{array}{c}(1) \\
\text { Covindex }\end{array}$ & $\begin{array}{c}(2) \\
\text { CovindexR }\end{array}$ & $\begin{array}{c}(3) \\
\text { CovindexR }\end{array}$ \\
\hline \multicolumn{4}{|l|}{ Independent variables } \\
\hline CovindexE & $\begin{array}{c}0.7768^{* * *} \\
(0.019)\end{array}$ & & \\
\hline dummyE & & $\begin{array}{c}0.0476^{*} \\
(0.026)\end{array}$ & \\
\hline dummybondE & & & $\begin{array}{c}0.0612^{* *} \\
(0.024)\end{array}$ \\
\hline \multicolumn{4}{|l|}{ Control variables } \\
\hline Maturity & $\begin{array}{c}0.0049^{* *} \\
(0.002)\end{array}$ & $\begin{array}{c}0.0045^{*} \\
(0.002)\end{array}$ & $\begin{array}{c}0.0054^{* *} \\
(0.002)\end{array}$ \\
\hline Leverage $_{t-1}$ & $\begin{array}{c}0.0003 \\
(0.000)\end{array}$ & $\begin{array}{c}0.0005^{*} \\
(0.000)\end{array}$ & $\begin{array}{c}0.0004^{*} \\
(0.000)\end{array}$ \\
\hline Size $_{t-1}$ & $\begin{array}{c}0.0077^{*} \\
(0.004)\end{array}$ & $\begin{array}{c}0.0109^{* *} \\
(0.005)\end{array}$ & $\begin{array}{c}0.0142^{* * *} \\
(0.005)\end{array}$ \\
\hline Growth & $\begin{array}{c}0.0119 * * * \\
(0.004)\end{array}$ & $\begin{array}{c}0.0116^{* *} \\
(0.005)\end{array}$ & $\begin{array}{c}0.0110^{* *} \\
(0.005)\end{array}$ \\
\hline dummyrating 1 & $\begin{array}{c}0.0499 * * * \\
(0.019)\end{array}$ & $\begin{array}{c}0.0451^{*} \\
(0.026)\end{array}$ & $\begin{array}{l}0.0400 \\
(0.025)\end{array}$ \\
\hline dummyrating2 & $\begin{array}{l}0.0300 \\
(0.025)\end{array}$ & $\begin{array}{c}0.0290 \\
(0.031)\end{array}$ & $\begin{array}{c}0.0238 \\
(0.031)\end{array}$ \\
\hline Creditspread & $\begin{array}{c}0.0159^{*} \\
(0.008)\end{array}$ & $\begin{array}{c}0.0253^{* *} \\
(0.012)\end{array}$ & $\begin{array}{c}0.0277^{* *} \\
(0.012)\end{array}$ \\
\hline MICEX & $\begin{array}{l}0.0000 \\
(0.000)\end{array}$ & $\begin{array}{l}0.0000 \\
(0.000)\end{array}$ & $\begin{array}{l}0.0001 \\
(0.000)\end{array}$ \\
\hline GDP & $\begin{array}{l}0.0035 \\
(0.004)\end{array}$ & $\begin{array}{l}0.0072 \\
(0.005)\end{array}$ & $\begin{array}{l}0.0079 \\
(0.005)\end{array}$ \\
\hline $\begin{array}{l}\text { Sector } \\
\text { Constant }\end{array}$ & $\begin{array}{c}\text { Yes } \\
-0.4433 \\
(0.388)\end{array}$ & $\begin{array}{c}\text { Yes } \\
-0.9741^{*} \\
(0.520)\end{array}$ & $\begin{array}{c}\text { Yes } \\
-1.0995^{* *} \\
(0.521)\end{array}$ \\
\hline $\begin{array}{l}\text { Observations } \\
R^{2} \\
F \text {-test }\end{array}$ & $\begin{array}{c}299 \\
0.856 \\
192.2 \\
(0.000)\end{array}$ & $\begin{array}{c}248 \\
0.162 \\
3.654 \\
(0.006)\end{array}$ & $\begin{array}{c}248 \\
0.147 \\
4.689 \\
(0.001)\end{array}$ \\
\hline
\end{tabular}

${ }_{660}$ a reduction in yield. Perhaps upon the development of the Russian debt market and as soon as the practice of including covenants in credit contracts becomes more widespread, the $\mathrm{CCH}$ will be defined as a characteristic of the domestic bond market as well, which will allow investors to manage and optimise risk and profitability and will enable borrowers to receive funds, minimising the weighted average cost of capital. The impact of covenant protection in Eurobonds on the domestic Russian market confirms that the mechanism of debtholders' interest protection in Russia is realised weakly. This finding suggests an urgent need to reduce information asymmetry through stronger transparency requirements on debt issuers in Russian capital markets and to increase creditor rights in Russia. Second, given the importance of covenants in the control of risk, Russian rating agencies could include a careful analysis of the covenant protection contained in bond indentures as a criterion of credit rating assessments. 
Table 12: Placebo tests regarding the relation between covenant protection and risk (Hypothesis 2 ). Specification (1) regards the firms that issue a bond in the sample period, and specifications (2) and (3) regard the firms that issue a bond in Russian market. The value shows the percentage of coefficients at $5 \%$ significance over 200 simulations. All variables are defined in Tab. C

\begin{tabular}{|c|c|c|c|}
\hline Dependent variable & $\begin{array}{c}(1) \\
\text { Covnum } \\
\end{array}$ & $\begin{array}{c}(2) \\
\text { CovnumR }\end{array}$ & CovnumR \\
\hline $\begin{array}{l}\text { Independent variables } \\
\text { CovnumE } \\
\text { dummyE } \\
\text { dummybondE }\end{array}$ & $3 \%$ & $4.5 \%$ & $2.5 \%$ \\
\hline $\begin{array}{l}\text { Control variables } \\
\text { Maturity } \\
\text { Leverage }_{t-1} \\
\text { Size }_{t-1} \\
\text { Growth } \\
\text { dummyrating1 } \\
\text { dummyrating2 } \\
\text { Creditspread } \\
\text { MICEX } \\
\text { GDP }\end{array}$ & $\begin{array}{c}4 \% \\
6 \% \\
5 \% \\
4 \% \\
2.5 \% \\
3 \% \\
2 \% \\
2.5 \% \\
2 \%\end{array}$ & $\begin{array}{c}4.5 \% \\
9 \% \\
4.5 \% \\
5.5 \% \\
2.5 \% \\
2.5 \% \\
3 \% \\
2 \% \\
0.5 \%\end{array}$ & $\begin{array}{c}4.5 \% \\
4.5 \% \\
4 \% \\
5.5 \% \\
1.5 \% \\
3.5 \% \\
3 \% \\
1.5 \% \\
2 \%\end{array}$ \\
\hline
\end{tabular}

\section{Acknowledgements}

We would like to thank two anonymous referees and the editor of the journal, Jonathan Batten. We also thank Amandeep Sahota, Andrzej Stopczynski, Lorenzo Caprio, Zhao Liping and the seminar participants at the PFN 2014 Conference in Faro, the IRMC 2014 Conference in Warsaw, the ADEIMF 2014 Conference in Milan, the FEBS 2016 Conference in Malaga, and the EFMA 2016 Conference in Basel for providing comments that were helpful in developing this study. The usual disclaimer applies.

\section{References}

Adam, T., \& Goyal, V. K. (2008). The investment opportunity set and its proxy variables. The Journal of Financial Research, 31, 41-63.

Aivazian, V. A., Ge, Y., \& Qiu, J. (2005). Debt Maturity Structure and Firm Investment. Financial Management, 34, 107-119.

Anderson, C. (1999). Financial contracting under extreme uncertainty: an analysis of Brazilian corporate debentures. Journal of Financial Economics, 51, 45-84.

Barclay, M. J., \& Clifford W Smith, J. (1995). The Maturity Structure of Corporate Debt. The Journal of Finance, 50, 609-631.

Barnea, A., Haugen, R. A., \& Senbet, L. W. (1981). Market Imperfections, Agency Problems, and Capital Structure: A Review. Financial Management, 10, 7-22.

Beatty, A., Ramesh, K., \& Weber, J. (2002). The importance of accounting changes in debt contracts: the cost of flexibility in covenant calculations. Journal of Accounting and Economics, 33, 205-227.

${ }_{695}$ Billett, M. T., Dolly King, T., \& Mauer, D. (2007). Growth Opportunities and the Choice of Leverage, Debt Maturity, and Covenants. The Journal of Finance, 62, $697-730$. 
Bradley, M., \& Roberts, M. (2015). The structure and pricing of corporate debt covenants. Quarterly Journal of Finance, 5, 1-37.

Chava, S., Kumar, P., \& Warga, A. (2004). Agency costs and the pricing of bond covenants. Unpublished Manuscript.

Chava, S., Kumar, P., \& Warga, A. (2010). Managerial Agency and Bond Covenants. The Review of Financial Studies, 23, 1120-1148.

Chava, S., \& Roberts, M. (2008). How Does Financing Impact Investment? The Role of Debt Covenants. The Journal of Finance, 63, 2085-2121.

Childs, P. D., Mauer, D. C., \& Ott, S. H. (2005). Interactions of corporate financing and investment decisions: The effects of agency conflicts. Journal of Financial Economics, 76, 667-690.

Correia, M. R. (2008). The choice of maturity and additional covenants in debt contracts: A panel data approach. Research in International Business and Finance, 22, 284-300.

Demerjian, P. (2017). Uncertainty and debt covenants. Review of Accounting Studies, 22, 1156-1197.

Demiroglu, C., \& James, C. (2010). The information content of bank loan covenants. The Review of Financial Studies, 23, 3700-3737.

Dichev, I., \& Skinner, D. (2002). Large-Sample Evidence on the Debt Covenant Hypothesis. Journal of Accounting Research, 40, 1091-1123.

Djankov, S., McLiesh, C., \& Shleifer, A. (2007). Private credit in 129 countries. Journal of Financial Economics, 84, 299-329.

720 Frankel, R., Seethamraju, C., \& Zach, T. (2008). GAAP goodwill and debt contracting efficiency: evidence from net-worth covenants. Review of Accounting Studies, 13, $87-118$.

Gong, G., Xu, S., \& Gong, X. (2017). Bond covenants and the cost of debt: Evidence from china. Emerging Markets Finance and Trade, 53, 587-610.

725 Goyal, V. (2005). Market discipline of bank risk: Evidence from subordinated debt contracts. Journal of Financial Intermediation, 14, 318-350.

Guedes, J., \& Opler, T. (1996). The Determinants of the Maturity of Corporate Debt Issues. The Journal of Finance, 51, 1809-1833.

Jensen, M. C., \& Meckling, W. H. (1976). Theory of the firm: Managerial behavior, agency costs and ownership structure. Journal of Financial Economics, 3, 305-360.

Kahan, M., \& Yermack, D. (1998). Investment Opportunities and the Design of Debt Securities. Journal of Law, Economics, \&3 Organization, 14, 136-151.

Kwan, S. H., \& Carleton, W. T. (2010). Financial Contracting and the Choice between Private Placement and Publicly Offered Bonds. Journal of Money, Credit and Banking , 42, 907-929. 
La Porta, R., Lopez-de Silanes, F., Shleifer, A., \& Vishny, R. (1997). Legal determinants of external finance. Journal of Finance, 52, 1131-1150.

Malitz, I. (1986). On Financial Contracting: The Determinants of Bond Covenants. Financial Management, 15, 18-25.

740 Mather, P., \& Peirson, G. (2006). Financial covenants in the markets for public and private debt. Accounting \& Finance, 46, 285-307.

Myers, S. C. (1977). Determinants of corporate borrowing. Journal of Financial Economics, 5, 147-175.

Nash, R., Netter, J., \& Poulsen, A. (2003). Determinants of contractual relations between shareholders and bondholders: Investment opportunities and restrictive covenants. Journal of Corporate Finance, 9, 201-232.

Nini, G., Smith, D. C., \& Sufi, A. (2009). Creditor control rights and firm investment policy. Journal of Financial Economics, 92, 400-420.

Nini, G., Smith, D. C., \& Sufi, A. (2012). Creditor Control Rights, Corporate Governance, and Firm Value. The Review of Financial Studies, 25, 1713-1761.

Niskanen, J., \& Niskanen, M. (2004). Covenants and Small Business Lending: The Finnish Case. Small Business Economics, 23, 137-149.

Paglia, J., \& Mullineaux, D. J. (2006). An empirical exploration of financial covenants in large bank loans. Banks and Bank Systems, 1, 103-122.

Park, C. W., Wang, R. R., \& Zou, H. (2013). Accounting-Based Debt Covenant Tightness and Management Earnings Forecasts. Unpublished working paper.

Prilmeier, R. (2017). Why Do Loans Contain Covenants? Evidence from Lending Relationships. Journal of Financial Economics, 123, 558-579.

Qi, Y., Roth, L., \& Wald, J. K. (2011). How legal environments affect the use of bond covenants. Journal of International Business Studies, 42, 235-262.

Qi, Y., \& Wald, J. K. (2008). State Laws and Debt Covenants. The Journal of Law and Economics, 51, 179-207.

Reisel, N. (2014). On the value of restrictive covenants: Empirical investigation of public bond issues. Journal of Corporate Finance, 27, 1-18.

Smith Jr, C. W., \& Warner, J. B. (1979). On financial contracting. Journal of Financial Economics, 7, 117-161.

Tanigawa, Y., \& Katsura, S. (2013). Covenants and Collateral in Japanese Corporate Straight Bonds: Choice and Yield Spread. Unpublished Manuscript.

Wang, J. (2017). Debt covenant design and creditor control rights: Evidence from the tightest covenant. Journal of Corporate Finance, 44, 331-352.

Wei, C. (2005). Covenant protection, credit spread dynamics and managerial incentives. Unpublished Manuscript.

White, H. (1980). A Heteroskedasticity-consistent Covariance Matrix Estimator and a Direct Test for Heteroskedasticity. Econometrica, 48, 817-838. 
Zhang, C. X., \& Zhou, S. (2015). Bond Covenants and Institutional Blockholding. Unpublished Manuscript.

Table 13: OLS regression with clustered standard errors regarding the relation between yield and covenant protection (Hypothesis 3). Specifications (1), (3), and (4) regard the firms that issue a bond in the sample period. Specification (2) regards the firms that issue a bond in the Russian market only in the sample period. All the variables are defined in Tab. C Standard errors in parentheses. $* * *, * *$, and $*$ denote significance at the $1 \%, 5 \%$, and $10 \%$ levels, respectively. Control for year and sector (see Tab. B) are as indicated.

\begin{tabular}{|c|c|c|c|c|}
\hline Dependent variable & $\begin{array}{c}(1) \\
\text { Yield }\end{array}$ & $\begin{array}{c}(2) \\
\text { Yield }(\mathrm{R})\end{array}$ & $\begin{array}{c}(3) \\
\text { Yield }\end{array}$ & $\begin{array}{c}(4) \\
\text { Yield }\end{array}$ \\
\hline \multicolumn{5}{|l|}{ Independent variables } \\
\hline Covindex & $\begin{array}{c}-4.2443^{* * *} \\
(0.746)\end{array}$ & & & \\
\hline CovindexR & & $\begin{array}{c}-0.2750 \\
(1.282)\end{array}$ & & \\
\hline CovindexE & & & $\begin{array}{c}-4.2456^{* * *} \\
(0.651)\end{array}$ & $\begin{array}{c}-1.5169^{*} \\
(0.787)\end{array}$ \\
\hline dummybondE & & & & $\begin{array}{c}-2.4218^{* * *} \\
(0.585)\end{array}$ \\
\hline \multicolumn{5}{|l|}{ Control variables } \\
\hline Maturity & $\begin{array}{l}0.0126 \\
(0.044)\end{array}$ & $\begin{array}{c}-0.0675^{*} \\
(0.038)\end{array}$ & $\begin{array}{c}-0.0080 \\
(0.045)\end{array}$ & $\begin{array}{c}-0.0215 \\
(0.040)\end{array}$ \\
\hline Leverage $_{t-1}$ & $\begin{array}{l}0.0084 \\
(0.007)\end{array}$ & $\begin{array}{l}0.0121^{*} \\
(0.006)\end{array}$ & $\begin{array}{l}0.0083 \\
(0.006)\end{array}$ & $\begin{array}{l}0.0087 \\
(0.006)\end{array}$ \\
\hline $\operatorname{Size}_{t-1}$ & $\begin{array}{c}-0.3393^{* * *} \\
(0.111)\end{array}$ & $\begin{array}{c}-0.3013^{* *} \\
(0.116)\end{array}$ & $\begin{array}{c}-0.3734^{* * *} \\
(0.108)\end{array}$ & $\begin{array}{c}-0.3822^{* * *} \\
(0.105)\end{array}$ \\
\hline Growth & $\begin{array}{c}-0.0009 \\
(0.186)\end{array}$ & $\begin{array}{l}0.0089 \\
(0.239)\end{array}$ & $\begin{array}{r}-0.0821 \\
(0.185)\end{array}$ & $\begin{array}{c}-0.0888 \\
(0.185)\end{array}$ \\
\hline dummyrating1 & $\begin{array}{l}0.5349 \\
(0.407)\end{array}$ & $\begin{array}{l}0.4137 \\
(0.341)\end{array}$ & $\begin{array}{l}0.2349 \\
(0.395)\end{array}$ & $\begin{array}{l}0.2364 \\
(0.382)\end{array}$ \\
\hline dummyrating2 & $\begin{array}{c}1.1517^{* *} \\
(0.550)\end{array}$ & $\begin{array}{c}1.2951^{* * *} \\
(0.420)\end{array}$ & $\begin{array}{l}0.7705 \\
(0.532)\end{array}$ & $\begin{array}{l}0.7199 \\
(0.520)\end{array}$ \\
\hline Creditspread & $\begin{array}{c}0.9040^{* * *} \\
(0.111)\end{array}$ & $\begin{array}{c}0.9369 * * * \\
(0.094)\end{array}$ & $\begin{array}{c}0.8488^{* * *} \\
(0.110)\end{array}$ & $\begin{array}{c}0.8385^{* * *} \\
(0.108)\end{array}$ \\
\hline Year & Yes & Yes & Yes & Yes \\
\hline Sector & Yes & Yes & Yes & Yes \\
\hline Constant & $\begin{array}{c}13.8620 * * * \\
(2.265)\end{array}$ & $\begin{array}{c}12.8427 * * * \\
(2.224)\end{array}$ & $\begin{array}{c}14.4859 * * * \\
(2.238)\end{array}$ & $\begin{array}{c}14.7720 * * * \\
(2.195)\end{array}$ \\
\hline Observations & 299 & 237 & 299 & 299 \\
\hline$R^{2}$ & 0.586 & 0.660 & 0.610 & 0.633 \\
\hline$F$-test & $\begin{array}{c}32.80 \\
(0.000)\end{array}$ & $\begin{array}{c}28.50 \\
(0.000)\end{array}$ & $\begin{array}{c}29.96 \\
(0.000)\end{array}$ & $\begin{array}{c}30.59 \\
(0.000)\end{array}$ \\
\hline
\end{tabular}


Table A: Classification of the different types of covenants in the covenant groups.

\begin{tabular}{ll}
\hline Covenant groups & Types of covenants \\
\hline Restrictions on investment policy & Restrictions on investment \\
& $\begin{array}{l}\text { Restrictions on the disposition of assets } \\
\text { Restrictions on a consolidation or merger } \\
\text { Requirements of the maintenance of assets }\end{array}$ \\
Restrictions on dividend payments & Limitations on debt and priority \\
Restriction of financing policy & Limitations on rentals, lease and sale-leaseback \\
& Cross default \\
Default-related covenants & Cross acceleration \\
& Required reports \\
Specifying bonding activities & Specification of accounting techniques \\
& Officers' certificate of compliance \\
& Required purchase of liability insurance \\
Event-related covenants & Hostile takeover \\
& Capital structure change \\
Rinancial covenants & Coverage ratio \\
& Leverage \\
& Net worth \\
& Current ratio \\
\hline
\end{tabular}

Table B: Sector definition used as a control variable in the empirical analysis.

\begin{tabular}{ll}
\hline Sector & Industry \\
\hline Agriculture & Agriculture \\
Construction & Construction materials production \\
& Construction and development \\
Mining & Mining industry \\
Services & Communication \\
& Retail \\
& Transportation \\
Manufacturing & Oil and gas service companies \\
& Textile industry \\
& Non-ferrous metals \\
& Food industry \\
& Ferrous metals \\
& Chemical and petrochemical \\
& Oil and gas \\
& Engineering industry \\
& Other sectors \\
& Power \\
\hline
\end{tabular}


Table C: Variables definitions and sources.

\begin{tabular}{|c|c|c|}
\hline Variable & Definition & Source \\
\hline \multicolumn{3}{|c|}{ Covenant protection } \\
\hline Covnum & $\begin{array}{l}\text { Number of covenant groups included in indenture } \\
\text { agreements }\end{array}$ & Cbonds.ru \\
\hline CovnumR & Covnum for Russian domestic bond issuers & Cbonds.ru \\
\hline CovnumE & Covnum for Eurobond issuers & Cbonds.ru \\
\hline dummybondR & $\begin{array}{l}\text { Dummy }=1 \text { if the firm places bonds on the Rus- } \\
\text { sian domestic market in a certain year and zero } \\
\text { otherwise }\end{array}$ & Cbonds.ru \\
\hline dummybondE & $\begin{array}{l}\text { Dummy }=1 \text { if the firm places Eurobonds in a } \\
\text { certain year and zero otherwise }\end{array}$ & Cbonds.ru \\
\hline dummyE & $\begin{array}{l}\text { Dummy }=1 \text { if the firm has outstanding Eurobonds } \\
\text { and zero otherwise }\end{array}$ & Cbonds.ru \\
\hline \multicolumn{3}{|c|}{ Issue characteristics } \\
\hline Maturity & Maturity in years & Cbonds.ru \\
\hline Yield & Nominal yield to maturity & Cbonds.ru \\
\hline dummyrating1 & $\begin{array}{l}\text { Dummy = } 1 \text { if the issuer's credit rating is equal } \\
\text { to "below investment" grade }\end{array}$ & Cbonds.ru \\
\hline dummyrating2 & $\begin{array}{l}\text { Dummy }=1 \text { if a firm is not rated or the rating } \\
\text { was withdrawn }\end{array}$ & Cbonds.ru \\
\hline \multicolumn{3}{|c|}{ Firm characteristics } \\
\hline Leverage & $\begin{array}{l}\text { The ratio of the firm's total debt to the firm's book } \\
\text { value of assets }\end{array}$ & Interfax \\
\hline Size & Natural logarithm of assets & Interfax \\
\hline Growth & $\begin{array}{l}\log \text { Sales }_{t}-\log \text { Sales }_{t-1} \text {, where } \log \text { Sales }_{t} \text { and } \\
\log \text { Sales }_{t-1} \text { are natural logarithm of sales revenue } \\
\text { in years } t \text { and } t-1 \text {, respectively }\end{array}$ & Interfax \\
\hline \multicolumn{3}{|c|}{ Market characteristics } \\
\hline Creditspread & $\begin{array}{l}\text { Credit spread of corporate bonds over the average } \\
\text { yield of the OFZ market }\end{array}$ & Cbonds.ru \\
\hline GDP & Gross domestic product index & WDI \\
\hline MICEX & $\begin{array}{l}\text { Capitalisation-weighted composite index of the } 50 \\
\text { most liquid Russian stocks }\end{array}$ & Moscow Exchange \\
\hline
\end{tabular}

